\title{
Scientific Haze
}

\author{
Goran Mijić (Salt Lake City)
}

\begin{abstract}
This essay concentrates on scientific-rationalist discourses entering massively the realm of literature at the beginning of the 20th century. They open new horizons revealing phenomena unknown before on the one side, but they also obscure the world around us providing convenient screen from painful truths on the other. This paper tries to demonstrate how technological discourses move the reader from a highly visual receptive position to a pure cognitive realm of symbolic representations with its own dynamics. The scientific-rationalist discourses produce a new parallel reality, a scientific haze tending to withdraw from visual representation.
\end{abstract}

With this paper I intend to show how various scientific discourses, after being treated only superficially by the German authors of the 19th century ${ }^{1}$, enter massively the realm of literature at the beginning of the 20th century, changing significantly its textual essence and the general world picture it represents. The impact of revolutionary advances in technology, industry and sciences on the life of an average citizen is enormous and could not be kept away from the literary arts any more. The changed perception and experience of city dwellers is registered in the works of modernist authors. The enormous inflation of technological vocabulary in early 20th century novels affects the perception, understanding, and judgment of a reader, and I will try to show how.

In the first part of my paper I will confine myself to the phenomenon of inflation of scientific vocabulary (meteorological vocabulary in particular) and devaluation of meaning as a result of the same.

In the second part of my paper, the technical terminology is recognized as an outer form of life (illusions) opposite to myth and spirituality ${ }^{2}$, and in particular to true being in Heidegger's sense. The scientific discourse has a comforting effect, for it distances a subject from a painful reality. Using an example from Döblin's Berlin Alexanderplatz, I will show how the scientific discourses distance the reader from the horror of Franz Biberkopf's evil deed. Then I will argue how a character from Musil's Der Mann ohne Eigenschaften is first confronted with the unpleasant picture of death and then comforted by the technical vocabulary and public procedure into an illusive routine. The "organic reality" is again transformed into a rational symbolic net.

In order to gain transparency, I will focus my analysis in the first part of my work on one scientific discourse, and that is meteorology. I will present three scenes from three different

\footnotetext{
${ }^{1}$ Cf. Segeberg (1987: 8-11).

${ }^{2}$ Simmel (1900/1990: 482).
} 
novels describing weather. The first scene taken from Fontane's Effi Briest, in which the weather is observed in a poetic and psychological way, serves as a contrast to the other two: Döblin's Berlin Alexanderplatz and Musil's Mann ohne Eigenschaften, where the weather is observed in a strictly positivistic way.

\section{Effi Briest}

Inzwischen war Mitte November herangekommen, und der bis zum Sturm sich steigernde Nordwester stand anderthalb Tage lang so hart auf die Molen, daß die mehr und mehr zurückgestaute Kessine das Bollwerk überstieg und in die Straßen trat. Aber nachdem sich's ausgetobt, legte sich das Unwetter, und es kamen noch ein paar sonnige Spätherbsttage.

"Wer weiß, wie lange sie dauern", sagte Effi zu Crampas, und so beschloß man, am nächsten Vormittag noch einmal auszureiten. (Fontane 1895/1996: 121).

Theodor Fontane, who is mostly classified by literary historians as a realist on the brink of modernism, paints by means of a weather description the psychological inner landscapes of the main character Effi. After marrying an elderly cultured diplomat, the 17-year-old Effi spends her days mostly alone in a cold spooky house waiting for her husband. Out of despair she becomes involved in an affair with the womanizer Crampas. The weather description is a metaphor, which is embedded in the plot and stands for Effi's departure from the "right" path. It is an anticipation of the coming disaster: "die mehr und mehr zurückgestaute Kessine überstieg das Bollwerk und trat in die Straßen ." Another function of the weather description is the description of the inner state of the main character, where "zurückgestaute Kessine and ihre Übersteigung" stand for Effi's accumulated feelings of powerless hatred and its release, and "ein paar sonnige Spätherbsttage. 'Wer weiß, wie lange sie dauern' " for the fear that there are only a few sunny days left before the long winter (punishment - Effi's excommunication).

Although it is described by and from the position of an omnipresent author, this weather is a single-weather which is closely tide up with the individual fate of the main character. After the weather description is given by the narrator, the sentiment of the main character is confirmed in her direct speech: "'Wer weiß, wie lange sie dauern' sagte Effi" and it corresponds to the weather description, or to say better, it writes further the one and the same narrative stream, and that is the inner world of the character. ${ }^{3}$

Fontane's poetic weather picture is exchanged for the scientific one in the following weather description in Berlin Alexanderplatz.

\footnotetext{
${ }^{3}$ I offer two other examples of this narrative technique, which is very wide-spread in Fontane's work:

"Es war ein wunderschöner Tag; der in einem zierlichen Beet um die Sonnenuhr herum stehende Heliotrop blühte noch, und die leise Brise, die ging, trug den Duft davon zu ihnen herüber. 'Ach, wie wohl ich mich fühle', sagte Effi." (Fontane 1895/1996: 28)

"Effi, die, still in sich versunken, jedes Wort halb ängstlich, halb begierig eingesogen hatte, richtete sich etzt auf und sah nach rechts hinüber, wo der Mond, unter weißem, aber rasch hinschwindendem Gewölk, eben aufgegangen war. Kupferfarben stand die große Scheibe hinter einem Erlengehölz und warf ihr Licht auf eine breite Wasserfläche, die die Kessine hier bildete. Oder vielleicht war es auch schon ein Haff, an dem das Meer draußen seinen Anteil hatte. Effi war wie benommen. 'Ja, du hast recht, Geert, wie schön; aber es hat zugleich so was Unheimliches.'" (Fontane 1895/1996: 44-45)
} 
Berlin Alexanderplatz

Wechselndes, mehr freundliches Wetter, ein Grad unter Null. Für Deutschland breitet sich ein Tiefdruckgebiet aus, das in seinem ganzen Bereich dem bisherigen Wetter ein Ende bereitet hat. Die geringen vor sich gehenden Druckveränderungen sprechen für langsame Ausbreitung des Tiefendruckes nach Süden, so daß das Wetter weiter unter seinem Einfluß bleiben wird. Tagsüber dürfte die Temperatur niedriger liegen als bisher. Wetteraussichten für Berlin und weitere Umgebung. (Döblin 1929/1994: 40).

This is a professional meteorological report. A specialist steps in the place of the poet providing the reader with a detailed weather description. It is a highly positivistic description that uses an exact meta-language behind which stands the application of the meteorological map and other measuring instruments. But the position from which this expert narrates cannot be exactly localized. The narration is depersonalized through the public voice of the narrator, who can come from the radio, or from the weather column of a local newspaper, or from somewhere else.

If we describe the narrative style of Effi Briest as a symphony with a repeating theme and a melody which flows elegantly through a permanently evolving psychological chain of causes and effects, then we can interpret Berliner Alexanderplatz (BA) as a dissonant work whose narrative flow is constantly and harshly interrupted eavesdroping on the polyphony of the city: different noises, different discourses, as if someone had thrown pictures one over another without order. BA is based on simultaneity and not continuity. That means that the meteorological report is only one among many other pictures and is directly interlocked with none of the following: the narrative-continuum, plot or the main character Franz Biberkopf. In comparison with Fontane's "individual" weather, the weather description in BA is a public event. The factual narrating addresses all inhabitants of Berlin and is untied from both the main character and his inner life, as well as from the narrator. Generally speaking, the direct epic bond between man and nature is broken.

However, since the weather report is neither the projection of the character's emotional world onto nature nor the effortful tool in the big plan of the auctorial narrator, one asks what is the function of the weather report as detached empirical description in the novel BA.

In my view, the weather report is not an end in itself, but it has, together with other factual parts, a cumulative effect. The weather report stands close to other reality shreds (listing of the trolley stops, companies, etc.) which are put together without the red thread in the art of a mosaic. As the narrator, who guides the reader through the text with her/his unifying perspective and smooth transitions, is for the big part absent (especially the scenes describing the city Berlin), the reader has to work hard by themselves. Going from one cluster of information to another, she/he makes connections constructing a picture of one part of Berlin (der Rosenthaler Platz here) whose clarity keeps increasing the further she/he proceeds. And the abstract unity Berlin is one of the main characters of the novel, as Döblin says, the counterpart of Franz Bieberkopf ${ }^{4}$, who wills the good, but gets lost in the kingdom of the dark

\footnotetext{
4 "Da dachte er (Franz Bieberkopf) nun, aus der Zelle kommend, es ließe sich frisch, frölich, frei ein neues Leben beginnen. Aber da hatte sich draußen nichts verändert, und er selber war der gleiche geblieben. Wie sollte da ein neues Resultat entstehen? Offenbar nur, indem einer von den beiden zerstört wurde, entweder Berlin oder Franz Bieberkopf." (Döblin 1929/1994: 414).

The similar "figure-constellation", where the city functions as an antagonist, can also be detected in numerous American "big city novels" at the end of the 19th and the beginning of the 20th century: William Dean Howell's
} 
forces of the city. To recap, then, although Döblin's positivistic writing looks like and very often is a chaotic flood and absurd mosaic of disparate reality shreds, the weather report in BA is a part of a greater picture which flickers in the reader's brain, where Berlin becomes a Pandemonium, but it is not only the meeting place of the evil ghosts, but also the meeting place of the rational ghosts who are floating over Berlin's ground.

In the century of technology, in which rational ghosts are hovering in idle motion escaping human control ${ }^{5}$, Urlich, the protagonist of Der Mann ohne Eigenschaften (MoE), finds no order of the whole; therefore, he takes a one-year vacation from his life in order to find out the cause and the secret mechanism of the disintegrated reality. Robert Musil (1880-1942), the author, starts his novel with a weather report, which is also the beginning of the first chapter entitled: "Erstes Kapitel - Woraus bemerkenswerter Weise nichts hervorgeht." After these words, it is senseless to look for the function of the weather report within the text. The title is the author's suggestion to enter the text without great expectations, anticipations of the coming intrigue, goal-seeking, and other false connections, for there is no linear cause-effect connection, as we concluded in BA, but only relations within an immense complex system. ${ }^{6}$

Musil's weather report, compared with Döblin's, is an intensification of the empirical discourse. Robert Musil, the son of an engineering professor, who tried several fields (military, mechanical engineering, philosophy, psychology) before deciding to be an author, possesses an enormous knowledge of science and technology.

\section{Der Mann ohne Eigenschaften}

Über dem Atlantik befand sich ein barometrisches Minimum; es wanderte ostwärts, einem über Russland lagernden Maximum zu, und verriet noch nicht die Neigung, diesem nördlich auszuweichen. Die Isothermen und Isotheren taten ihre Schuldigkeit. Die Lufttemperatur stand in einem ordnungsgemäßen Verhältnis zur mittleren Jahrestemperatur, zur Temperatur des kältesten wie des wärmsten Monats und zur aperiodischen monatlichen Temperaturschwankung.

Der Auf- und Untergang der Sonne, des Mondes, der Lichtwechsel des Mondes, der Venus, des Saturnringes und viele andere bedeutsame Erscheinungen entsprachen ihrer Voraussage in den astronomischen Jahrbüchern. Der Wasserdampf in der Luft hatte seine höchste Spannkraft, und die Feuchtigkeit der Luft war gering.

Mit einem Wort, das das Tatsächliche recht gut bezeichnet, wenn es auch etwas altmodisch ist: Es war ein schöner Augusttag des Jahres 1913. (Musil 1930/1999: 9).

\footnotetext{
A Hazard of New Fortunes (1889), Stephan Crane's Maggie, a Girl of the Streets (1896), Theodor Dreiser's Sister Carrie (1900), and An American Tragedy (1925). Cf. Schaller (1998: 106-107).

5 "Seit Balzac ist die menschliche Existenz nicht ohne ihre historischen Wurzeln verständlich. Mit seiner Erforschung der Figuren und ihrer Situationen stellt Musil eine existentielle Diagnose seines Jahrhunderts. Tatsächlich ist in seinem Kakanien schon alles da: die Herrschaft der Technik, die niemand beherrscht und die den Menschen zu statistischen Zahlen reduziert hat (mit diesem Thema beginnt der Roman)." Kundera (1999).

${ }^{6}$ This is also a central point of the Austrian physicist and philosopher of science Ernst Mach (1838-1916), who was concerned with causality. Robert Musil prepared a doctoral dissertation on Ernst Mach. Cf. Mehigan (1997).
} 
Although there is an omnipresent and all-knowing narrator in the traditional sense of the expression (God's view) in MoE, this is only an ironical gesture ${ }^{7}$ of the author. The novel begins with an omniscient narrator who is also all-knowing in the sense of being familiar with all scientific discourses of the time, and who functions here at the beginning of the novel as a meteorologist, somewhere else as a technician, etc. Here, the reader faces a radically changed narrator's view, whose scientific intelligence de-romanticizes the landscape and tradition of "fine literature." The author puts on scientific glasses, where one glass is a weather chart and another a climatic map, which changes the picture of landscape dramatically.

The narrator as a specialist dissects nature along lines laid down by the professional language from one field of specialization and consequently changes the way the readers experience nature. The scientific maps step into the place between wo/men and landscape, breaking the directness of phenomenological perception and correspondingly destroying the mystical bond between human being and nature.

This tendency has the shrinking of the humane sphere as a consequence. In contrast to Fontane's sentimental tone, Musil begins his novel in a cool empirical voice.

General measures replace the individual poetically expressed perception. The systematizing of the landscape (natural phenomena) destroys the holistic view by particular descriptions. There are too many micro details, facets, and this complexity leads to a perception denial and blindness. It is a disintegration that cannot be handled intellectually, for it defies a humane holistic representation.

As the Frankfurt School scholars realized, an irrational tendency is inherent in the rational exactitude. In our weather report the abstract invisible measures ramble across the ocean and country like some kind of rational phantoms: "Über dem Atlantik befand sich ein barometrisches Minimum; es wanderte ostwärts, einem über Russland lagernden Maximum zu, und verriet noch nicht die Neigung, diesem nördlich auszuweichen." (Musil 1930/1999: 9)

By objectifying natural phenomena with specialized vocabulary like "barometrisches Minimum/Maximum, Isothermen/Isotheren," the meteorological discourse, unified by the weather chart and climate map, becomes a machine, which does not need a reader. Rational spiritless machinery with its abstract vocabulary, relations, and systems comes off the human being and begins an independent existence ${ }^{8}$. I want to speculate that the meteorological report is neither the construct of the reader, nor the word of the author, but a scientific discourse of the time, whose mechanics function automatically regardless whether a reader understands them or not.

The discursive mechanics of the meteorological discourse do not create a clear objective picture of nature (natural phenomena), but rather a scientific cloud, which allows no representation, no imagination, no picture.

Codified specialized language has an alienating effect, and instead of sharpening it fades space borders. It also causes a communication problem, for the weather report in $\mathrm{MoE}$ is hardly understandable and probably skipped by an average reader because of the codified description.

\footnotetext{
${ }^{7}$ Cf. Rasch (1967).

${ }^{8}$ The protagonist of MoE Urlich realizes the same tendency in the anthropological and psychological sense claiming the existence of "Eigenschaften ohne Mann", which is certainly one of the main keys of the novel.
} 
Apart from the phenomenon of blurring of the visual representation by specialized languages, the literary text as a scientific code has another alienating effect and that is the distancing the reader from the horror event or a sensuous experience in general. In the last chapter of the second book BA, Döblin breaks the description of Ida's death through the inserted parts from the Greek saga about the death of Agamemnon. The comparison of a mythological description of death with a modern one requires closer attention here. Whereas the Greek murder scene is followed by excessive feeling, the narrator's retrospective view on Ida's murder in BA radiates an insensible coldness.

Already the message of Agamemnon's return is highly emotionally charged: "Sie [Meldung] brennt, sie lodert, in jedem Augenblick, an jedem Ort sagt sie, fühlt sie, und alles jauchzt darunter." (Döblin 1929/1994: 87). The message flows like hot blood through the veins of an ancient collective organism. The death of Agamemnon, who was killed by his wife Clytemnestra, is a collective experience, in which the whole community takes part. "Agamemnon kommt! Tausend Menschen glühen an jedem Ort auf: Agamemnon kommt, und jetzt sind es zehntausend, über dem Meerbusen hunderttausend"(Döblin 1929/1994: 87). Like a Dionysian chorus, they are involved in the drama commenting and emphasizing the terror. While Agamemnon groans heavily inside: "Weh mir, getroffen!" (Döblin 1929/1994: 87), outside they ask: "Wer schreit da über sich?" (Döblin 1929/1994: 87)

The murder scene, as well as a scene before with the Furies, is accompanied by exclamations of terror: "Weh mir und wieder", "Hoi ho hatz", "O Greuel, Greuel" (Döblin 1929/1994: 86). It is a Dyonisian reveling and ecstatic suffering raised to a communal joint ecstasy. The whole collective is united in a joint experience of suffering confronted with the truth/reality which is revealed by the presence (emotional experience) of death - finiteness of being.

In opposition to Agamemnon's death, Ida's murder is presented by a series of cold scientific discourses which detach the reader from the horror of Franz's deed.

The description of Ida's murder begins with a list of damaged organs typical for a court record: " [...] die Haut über der Nase am spitzen Teil und in der Mitte, der darunter liegende Knochen mit dem Knorpel [...] die rechte und linke Schulter " (Döblin 1929/1994: 85). Then the murder weapon and the motive of the murder are described. In order to describe what happened to Ida's diaphragm, Döblin involves the laws of statics, elasticity, and resistance, as well as two of Newton's laws of motion. After that, a view inside Ida's body is enabled through a post-mortem examination providing the reader with the medical explanation of the cause of death . Ida is lying dissected in the Friedrichshain hospital: " [...] komplizierter Rippenbruch, Riß im Brustfell, kleiner Lungenriß, anschließendes Empyem, Brustfellvereiterung, Lungenentzündung"(Döblin 1929/1994: 88).

Although we can follow step by step with scientific accuracy what happened to Ida, our senses are confused through the regularity of the above mentioned discourses. The terrible scene is not supported by exclamation of horror or other kind of sensuous exaggeration as in the Greek saga. There is no pity on a person. People are not united by a joint humane reality conditio humanis, suffering, compassion, but they are rather - as Hungarian Marxist philosopher Lukacs defines the modern subject in his Theory of the Novel - alienated, homeless, fragmented, and lonely (Cf. Lukacs 1920/1999).

However, although Döblin bypasses the compassionate sentiment, the murder of Ida is also far from a "realistic" description. There are clearly some personal aspects of the relationship between Ida and Franz in this chapter, but the truth is that the public discourses dominate the 
whole scene. The accumulation of information strips Ida of her individuality and files her into one of the cases of public statistics. Instead of realistic description, Döblin offers a series of public procedures (court record, factual statement, medical record) beyond which Ida disappears, while Franz, on the other side, this "basically good man", gets an almost heroic epithet - a roaring lion, which reinforces his differentiated individuality. The mingling of public and private spheres, or to put it better, the superiority of the public and general over the private and specific has an effect of leveling-down of the experience and standardization of men as a result.

The standardization, or rather the covering of the event with scientific procedures, blurs the picture of terror. Despite the detailed description - we can say there is no single unknown quantity in Döblin's description - we can hardly claim that the whole terror scene is as transparent as it can be. Or to be honest, not at all. Instead of a personal description supported by metaphors and metonymies, Döblin uses stereotyped language, which is reproduced countless times in everyday life, and which reduces the horror of Franz's deed to public lists, records, formulas, laws of physics, vertical and horizontal lines, etc. To recap, although the scientific discourses clarify different aspects of Ida's death, this depersonalized language in general also blurs the picture and causes a perception denial on the side of the reader who is in this way kept at a distance from Franz's barbaric act.

The death, as one of the most unpleasant moment in human life, managed and controlled by men and their rational institutions, is also the theme of the last aspect of technological discourse with which I want to close my paper. The motif of death, or to be more exact, the proximity of death, has always had a momento mori function in literature. The dance macabre in the Middle Ages evoked the futility of all earthly treasures, and later in the same sense Dickens' Christmas Carol and Hofmannsthal's Jedermann und Der Thor und der Tot alluded to the invalidity of property and the discovery of genuine values. Here I want to make an assumption that in the years of rising industrialization of society, whose rationalizing mechanisms enter the realm of literature, the topos of death gets an additional enlightening function which could be described as follows: Death makes the rational net transparent and its frictionless functionalism fragile. It is a kind of resistance in nature itself ${ }^{9}$ that breaks through the rational spider web and makes one self-forgotten. In the accident scene from MoE we can see how the picture of death brings the rational city flow to a standstill, confronts a subject with the truth - finiteness of his/her own existence, and then is finally absorbed by the rational routine of public services.

A man has been hit by a truck and is lying on the ground. The crowd is gathered around him. A pair approaches the scene of the accident:

Auch die Dame und ihr Begleiter waren herangetreten und hatten, über Köpfe und gebeugt Rücken hinweg, den Daliegenden betrachtet. Dann traten sie zurück und zögerten. Die Dame fühlte etwas Unangenehmes in der HerzMagengrube, das sie berechtigt war für Mitleid zu halten; es war ein unentschlossenes, lähmendes Gefühl.

Der Herr sagte nach einigem Schweigen zu ihr: "Diese schweren Kraftwagen, wie sie hier verwendet werden, haben einen zu langen Bremsweg." Die Dame fühlte sich dadurch erleichtert und dankte mit einem aufmerksamen Blick. Sie

\footnotetext{
${ }^{9}$ My opinion is that there is a resistance in nature itself toward the human rational plan of controlling nature. For instance, it is proved that nature reacts (of course not rationally but consequentially) to the pollution of the environment in form of changes in climate, raging storms, etc.
} 
hatte dieses Wort wohl schon manchmal gehört, aber sie wußte nicht, was ein Bremsweg sei, und wollte es auch nicht wissen; es genügte ihr, daß damit dieser gräßliche Vorfall in irgendeine Ordnung zu bringen war und zu einem technischen Problem wurde, das sie nicht mehr unmittelbar anging. Man hörte jetzt auch schon die Pfeife eines Rettungswagens schrillen, und die Schnelligkeit seines Eintreffens erfüllte alle Wartenden mit Genugtuung. Bewundernswert sind diese sozialen Einrichtungen. Man hob den Verunglückten auf eine Tragbahre und schob ihn mit dieser in den Wagen. Männer in einer Art Uniform waren um ihn bemüht, und das Innere des Fuhrwerks, das der Blick erhaschte, sah so sauber und regelmäßig wie ein Krankenhaus aus. Man ging fast mit dem berechtigten Eindruck davon, daß sich ein gesetzliches und ordnungsgemäßes Ereignis vollzogen habe.

"Nach den amerikanischen Statistiken", so bemerkte der Herr, "werden dort jährlich durch Autos 190.000 Personen getötet und 450.000 verletzt."

"Meinen Sie, daß er tot ist?" fragte seine Begleiterin und hatte noch immer das unberechtigte Gefühl, etwas Besonderes erlebt zu haben.

"Ich hoffe, er lebt", erwiderte der Herr. "Als man ihn in den Wagen schob, sah es ganz so aus." (Musil 1930/1999: 11).

The busy street came to a sudden stop for something there had broken ranks: "Etwas war aus der Reihe gesprungen, eine quer schlagende Bewegung; etwas hatte sich gedreht, war seitwärts gerutscht"(Musil 1930/1999: 10). The accident causes the collapse of the city order. A man hit by a truck is lying on the curb as if dead. The lady is struck by the scene. The picture of death penetrates her privileged social bearing, style of dress, and conversation ${ }^{10}$, causing a queasy feeling in the pit of her heart/stomach. Or in more philosophical terms, true being, usually buried under the numerous cognitive layers of ordinary city routines, penetrates the rational net of symbolic representations and causes its fall. The lady is overcome by the fear for her own existence. The proximity of death makes her hesitant, irresolute, and helpless. It causes her to forget herself, to fall out of her role, but it gives her something back, something she lost a long time ago, and that is compassion, the secret bond with another human being and the world around her. Death as the dark invisible shadow, resistance in nature itself, shakes the very basis of human existence. "The invisible shadow is cast around all things everywhere when man has been transformed into subiectum and the world into picture." (Heidegger 1954/1977: 135).

But her suffering does not last for a long time. The gentleman explains the state of affairs with the following words: "Diese schweren Kraftwagen, wie sie hier verwendet werden, haben einen zu langen Bremsweg." (Musil 1930/1999: 11) The technical word Bremsweg creates the magic. The lady is relieved, although she does not really understand or care to understand what the word means. The gentleman's explanation helps put this ghastly incident into perspective by reducing it to a technicality of no direct personal concern to her. The lady does not believe her eyes, but relies on a technical magic word behind which there is no visual representation (she does not know what the word means) but only the scientific haze. She does not believe her inner feeling but in an external appearance, a rational ghost of security. She prefers to set something before herself, the scientific glasses with painted spectacle lens, in order not to see. She prefers the technical haze to the painful reality.

\footnotetext{
${ }^{10}$ Before the accident, the narrator describes the couple as follows: "Die beiden Menschen gehörten ersichtlich einer bevorzugten Gesellschaftsschicht an, waren vornehm in Kleidung, Haltung und in der Art, wie sie miteinander sprachen" (Musil 1930/1999: 10).
} 
Soon the ambulance comes and takes care of the victim. All bystanders are relieved and grateful to the society which is functioning admirably: "Man ging fast mit dem berechtigten Eindruck davon, daß sich ein gesetzliches und ordnungsgemäßes Ereignis vollzogen habe." (Musil 1930/1999: 11) The gentleman reinforces the impression of the regularity of the event by quoting the exact number of people killed and injured every year by cars and so incorporating the case into the anonymity of statistics. The lady, now encouraged by this triumph of modern society, has an unjustified feeling that she has experienced something unusual.

The rational web woven by the society and its procedures is revealed by the proximity of death as a decisive reality. Death confronts the subject with true being. But then it is again encoded into a schema (technical vocabulary, statistics) and handled by the social institution.

To sum up the whole paper, we have seen how scientific discourses open new perspectives by explaining phenomena unknown before. At the same time they create a new parallel reality, a scientific haze escaping visual representation. This new reality is for the most part observable only within the cognitive realm. The scientific discourses have their own dynamics with a tendency to withdraw from visual representation. Reality is encoded in a rational net, an illusory picture, or rather a series of pictures that fit together perfectly like different parts of a city map, but the map is always outdated and many streets and buildings on it cannot be found once we sit in the car and are trying to find them.

Gottfried Benn recognized intellectualism as a martial attack on the fragmented human substance. ${ }^{11}$ Death, making manifest the artificial character of the rational system confronts a subject with her/his human substance and her/his long-lost totality. But it is experienced as a too painful and unpleasant experience, which should be quickly absorbed by a generalization, public routine, or rational procedures that function as a pacifier for a modern subject and his infantile longing for security.

\section{Refrences}

Heidegger, Martin (1954/1977): The Question Concerning Technology and Other Essays. New York.

Kundera,Milan (1999): "Mein Jahrhundertsbuch". Die Zeit. Ausgabe 4/1999.

Lukacs, Georg (1920/1999): The Theory of the Novel. Cambrige Massachusetts.

Mehigan, Tim J. (1997): "Robert Musil, Ernst Mach und das Problem der Kausalität". Deutsche Vierteljahrsschrift 71, 2 (June): 264-287.

Rasch, Wolfdietrich (1967): Über Robert Musils Roman der Mann ohne Eigenschaften. Göttingen.

Schaller, Hans-Wolfgang (1998): Der amerikanische Roman des 20. Jahrhunderts. Stuttgart.

Segeberg,Harro (1984): Literarische Technik-Bilder. Tübingen.

Simmel, Georg (1900/1990): The Philosophy of Money. London / New York.

\section{Primary sources:}

Döblin, Alfred (1929/1994): Berlin Alexanderplatz. München.

Fontane, Theodor (1895/1996): Effi Briest. München. (=Trautwein Klassiker-Edition).

Musil, Robert (1930/1999): Der Mann ohne Eigenschaften. Hamburg.

11 "Intellektualismus ist der kriegerische Angriff auf die zersetzte menschliche Substanz". 